\title{
Phytoplankton community structure in the river-influenced continental margin of the northern Gulf of Mexico
}

\author{
Sumit Chakraborty, Steven E. Lohrenz* \\ School for Marine Science and Technology, University of Massachusetts Dartmouth, 706 Rodney French Blvd., New Bedford, \\ Massachusetts 02744, USA
}

\begin{abstract}
Phytoplankton community composition was characterized over varying seasonal and river discharge conditions during 5 research cruises across the continental margin of the northern Gulf of Mexico (NGOM). The spatial and temporal patterns of variation in the composition of the algal community were examined using high performance liquid chromatography (HPLC) analyses of phytoplankton pigments in conjunction with classification using the CHEMTAX software (v.1.95). Cluster analysis and principal component analysis were used to identify different regimes and to understand the relationship of the phytoplankton community to biological and environmental variables. The large river dominated margin of the NGOM was characterized by (1) an estuarine and inner shelf regime dominated by diatoms, cryptophytes, cyanobacteria, and chlorophytes; (2) midshelf waters, a transition zone between coastal river-influenced and oligotrophic slope waters, associated with a mixed phytoplankton composition; and (3) a slope water regime typical of oligotrophic ocean conditions with a surface community dominated by cyanobacteria, haptophytes, and prochlorophytes. A chlorophyll fluorescence maximum (CFM) was a regular feature at offshore stations and showed significant differences from that of surface waters in seasonal variability of phytoplankton pigment ratios and community composition. Our findings support the view that large river outflows, along with other environmental variables such as wind forcing and stratification, have a profound influence on phytoplankton communities over a large regional extent in the continental margin waters of the NGOM.
\end{abstract}

KEY WORDS: Phytoplankton community - Northern Gulf of Mexico · Pigments - CHEMTAX · Environmental forcing $\cdot$ Stratification $\cdot$ Mixing $\cdot$ Large river ecosystem

Resale or republication not permitted without written consent of the publisher

\section{INTRODUCTION}

Continental margin waters that receive input from large rivers are characterized by high biological productivity, intense biogeochemical cycling, and strong ecological gradients in environmental conditions and phytoplankton abundance and community composition (Smith \& Demaster 1996, Lohrenz et al. 2008, Zhou et al. 2008, Goes et al. 2014). The northern Gulf of Mexico (NGOM) is an example of such a large river system, strongly influenced by the MississippiAtchafalaya river system (the third largest river basin of the world, covering over $3.2 \times 10^{6} \mathrm{~km}^{2}$, draining $>80 \%$ of the continental USA; after Dunn 1996). This marine ecosystem is one of the most highly productive (>300 $\mathrm{g} \mathrm{C} \mathrm{m}^{-2} \mathrm{yr}^{-1}$, Heileman \& Rabalais 2008) continental margins of the world.

Prior studies that examined phytoplankton community variability in the immediate plume area of the Mississippi River and the inner shelf of the NGOM (Dortch \& Whitledge 1992, Dortch et al. 2001, Schaeffer et al. 2012) identified changes in river discharge and the associated variations in nutrient ratios, light and stratification to be important controlling factors. 
Additional studies have examined taxon-specific vertical flux rates (Fahnenstiel et al. 1995) and found that the highest loss rates for diatoms were strongly related to size and density (silicification). Dortch et al. (2001) also implicated diatoms as important vectors for carbon flux. A conclusion of these studies is the potential importance of variability in nutrient ratios (especially that of silicate to other nutrients) in altering phytoplankton community composition and the associated impacts on overall productivity and carbon flux. Understanding these processes is particularly important in this region because of their potential linkage to the widely recognized coastal eutrophication and associated hypoxia in the NGOM (Rabalais et al. 2002a). Seasonal hypoxia in the NGOM (also known as the Gulf of Mexico 'Dead Zone') is one of the largest in the coastal zones of the world (Rabalais et al. 2002b). The Mississippi River plume plays an important role in the formation of hypoxia (Justic et al. 1995, Rabalais et al. 2002a), and consequently, studies focusing on the Mississippi River outflow region (mainly west of the Mississippi Delta) have received considerable attention in the recent literature.

These prior studies of phytoplankton community composition have been limited in spatial and temporal extent and, in some cases, to only a few phytoplankton taxa. Consequently, information is lacking about the seasonal phytoplankton community dynamics in the NGOM shelf and adjacent offshore waters. Patterns of cross-shelf variations in phytoplankton community composition in the NGOM, particularly as they relate to gradients in salinity, have been described previously in the northwestern (Lambert et al. 1999) and northeastern Gulf of Mexico (Lambert et al. 1999, Qian et al. 2003). However, these studies lacked coverage in the central NGOM, which represents the area of predominant influence of the Mississippi-Atchafalaya river system, and they provided limited information about relationships to other variables such as nutrients, temperature, mixing and physical forcing (e.g. winds and currents).

In addition to the influence of river outflow on shelf waters, a number of studies have observed significant offshore transport events involving MississippiAtchafalaya river-influenced waters (Walker et al. 2005, Schiller et al. 2011, Zhang et al. 2012). To date, information about phytoplankton community composition in such offshore river-influenced features is limited to a single event (Wawrik \& Paul 2004), and the relationship between environmental conditions and phytoplankton community structure has yet to be examined in such features for different seasons and river discharge conditions.
The present study examined spatial and temporal patterns of phytoplankton community composition, based on phytoplankton pigment composition, across a large portion of the central NGOM, extending from freshwater bays and estuaries and the outflow regions of the Mississippi and Atchafalaya rivers to the oligotrophic slope and offshore waters outside the direct influence of the rivers. A comprehensive multivariate statistical analysis was applied to hydrological, chemical, and biological observations to (1) produce a characterization of the phytoplankton biomass and community structure regimes in the NGOM, and (2) determine seasonal variations in phytoplankton community composition in relation to different chemical and physical properties. We addressed the following fundamental questions: (1) What are the important environmental variables in addition to salinity (e.g. nutrients, stratification, wind forcing) associated with phytoplankton community dynamics in the Mississippi-Atchafalaya riverinfluenced margin of NGOM? (2) Is offshore transport of river-influenced waters associated with distinct phytoplankton community composition in the NGOM? Finally, we briefly comment on the ecological implications of our observations of phytoplankton community structure for hypoxia and carbon export in this region.

\section{MATERIALS AND METHODS}

\section{Study sites and sampling}

Five major cruises were conducted in the NGOM region to study the vertical and horizontal distribution of phytoplankton communities. Four cruises were conducted in 2009, including January (winter 2009), April (spring 2009), July (summer 2009), October/ November (fall 2009), as well as one in March 2010 (spring 2010). Samples were collected at approximately 50 discrete stations (Fig. 1) for phytoplankton pigments, inorganic nutrients and limited microscopic analyses of phytoplankton. Water samples and vertical profiles of temperature $(T)$ and salinity $(S)$ were recorded at each station using a vertical profiling package that included a SeaBird SBE911 plus CTD and rosette sampler equipped with 101 Niskin bottles. The package was also equipped with a chlorophyll fluorometer (Chelsea Instruments) and beam transmissometer (Sea Tech, $20 \mathrm{~cm}$ path length). Sampling depths for pigment analysis were selected by examining chlorophyll fluorescence profiles and choosing from at least 3 to 5 depths in the upper 


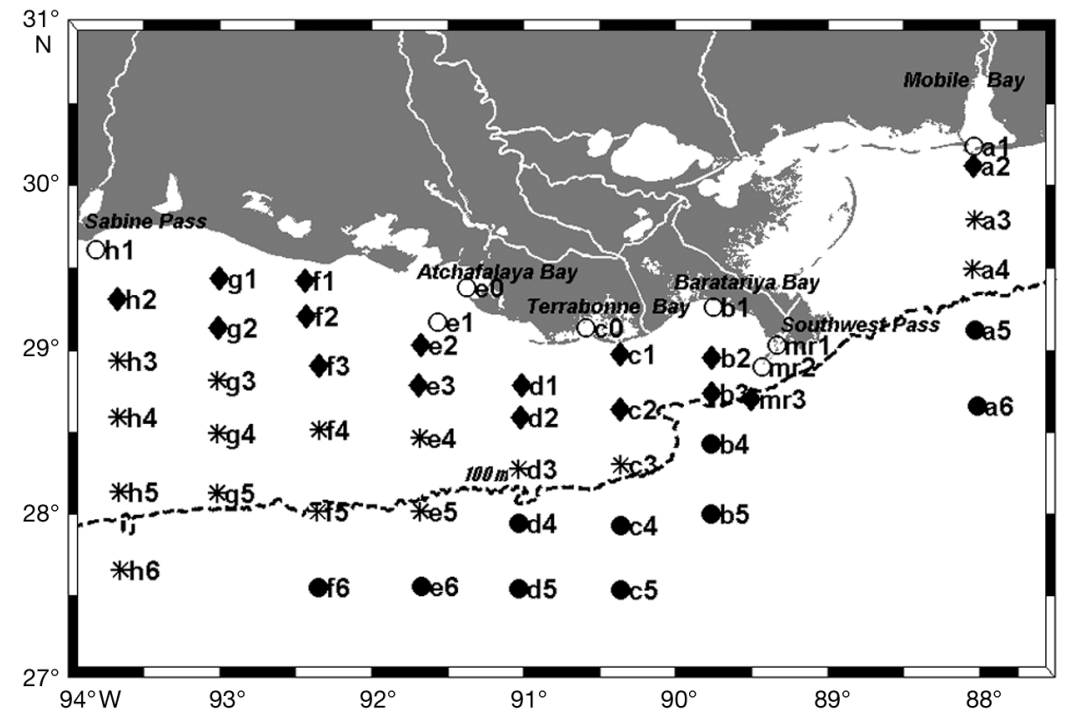

Fig. 1. Study area and stations sampled during the Gulf Carbon cruises. The letters and symbols denote the geographical locations of stations demarcating the different water masses found in the area: estuaries (O), inner shelf $(\diamond)$, midshelf $(*)$, and offshore/slope $(\bullet)$ waters. Cluster analysis was used to group the stations (see details in 'Materials and methods: Statistical analyses' and Fig. S1 in the Supplement at www.int-res.com/articles/suppl/m521p031_supp.pdf) bonate membrane filters. Filtered samples were stored at $-20^{\circ} \mathrm{C}$ in a small plastic Petri dish until returning to the lab. Samples were dried for $24 \mathrm{~h}$ at $60^{\circ} \mathrm{C}$ and weighed on a Mettler Precision Analytical Balance. This was repeated over 3 to $4 \mathrm{~d}$ until weight was stable.

Mixed layer depth (MLD) was determined at each station using a criterion of depth rate of change of density of $0.05 \mathrm{~kg} \mathrm{~m}^{-3}$ (Mitchell \& Holm-Hansen 1991). The stratification index was expressed as the Brunt-Väisälä frequency $(N)$, in rad s $\mathrm{s}^{-1}$, defined as:

$$
N=\sqrt{\frac{g}{\rho} \frac{\partial z}{\partial \rho}}\left(\operatorname{rad~s}^{-1}\right)
$$

where $g$ is gravitational acceleration $\left(9.8 \mathrm{~m} \mathrm{~s}^{-2}\right)$ and $\rho$ is the density of seawater in units of $\mathrm{g} \mathrm{m}^{-3}$. The Brunt-Väisälä frequency may also be expressed in cycles $\mathrm{s}^{-1}$ as $N_{\mathrm{f}}=N / 2 \pi$.
$200 \mathrm{~m}$ that included the upper mixed layer and subsurface chlorophyll fluorescence maximum (CFM) (when present). For station depths $25 \mathrm{~m}$ or less, only surface and near bottom samples were collected.

For microscopic enumeration of phytoplankton taxa, samples from selected stations were collected into $25 \mathrm{ml}$ bottles, preserved in glutaraldehyde (Sigma Grade I) to a final concentration of $0.1 \%$, and refrigerated for later analysis on shore. Phytoplankton abundance was determined using an epiflourescence microscope.

Samples for nutrients were initially filtered through Whatman $25 \mathrm{~mm}$ GF/F filters and refrigerated in acid-washed, polyethylene bottles until analysis on shore. Nutrient samples were collected at depths and included measurements of nitrate $\left(\mathrm{NO}_{3}\right)$, nitrite $\left(\mathrm{NO}_{2}\right)$, ammonium $\left(\mathrm{NH}_{4}\right)$, silicate $\left(\mathrm{SiO}_{3}\right)$ and phosphate $\left(\mathrm{PO}_{4}\right)$. Fluorometric methods were used for nitrogen species and spectrophotometric methods for $\mathrm{PO}_{4}$ and $\mathrm{SiO}_{3}$. All nutrient analyses were performed using an Astoria-Pacific A2+2 nutrient auto-analyzer (methods \#A179, A027, A205 and A221; Astoria Pacific International).

Suspended particulate matter (SPM) was determined by draining an entire Niskin bottle into a 201 carboy. Prior to withdrawing samples for filtration, the carboy was agitated to ensure uniform distribution of sample. Samples were filtered onto pre-tared, $0.45 \mu \mathrm{m}$ pore size, $45 \mathrm{~mm}$ diameter Poretics polycar-

\section{High performance liquid chromatography pigment analysis}

Seawater samples for pigment analyses were immediately filtered ( 2 to 51 volume) onto Whatman $47 \mathrm{~mm}$ GF/F filters under low vacuum $(<0.5 \mathrm{~atm})$. The filters were blotted dry, and stored in $2 \mathrm{ml}$ cryotubes (Fisher) in liquid nitrogen until analysis. Prior to extraction of the pigments, filters were lyophilized at -47 to $-52^{\circ} \mathrm{C}, 0.100$ mbar for $12 \mathrm{~h}$ (using a Labconco FreeZone 6 system) to remove excess water. The lyophilized filters were immersed in $90 \%$ acetone $(3 \mathrm{ml})$, vortexed, and the contents weighed prior to storing overnight at $-4^{\circ} \mathrm{C}$. Pigments were extracted by filtering the slurry (acetone and filter contents) through a $13 \mathrm{~mm}$ diameter $0.2 \mu \mathrm{m}$ polytetrafluoroethylene HPLC syringe filter (Alltech) attached to a $5 \mathrm{~cm}^{3}$ glass syringe. The clarified extracts were subsequently collected in disposable microcentrifuge tubes $(2 \mathrm{ml})$ and stored at $-19^{\circ} \mathrm{C}$ until analysis (usually less than $8 \mathrm{~h}$ ). Prior to injection, a 50:50 mixture of $350 \mu$ l of sample extract and $350 \mu$ letrabutylammonium acetate was prepared, adjusted to $\mathrm{pH}$ 6.5. The injection loop $(500 \mu \mathrm{l})$ was flushed and filled with the mixture and subsequently injected onto the column. The high performance liquid chromatography (HPLC) analysis method was similar to that of Van Heukelem \& Thomas (2001), with minor modifications. 


\section{CHEMTAX analysis}

CHEMTAX software v.1.95 (Mackey et al. 1996, Roy et al. 2011) was used to determine contributions of phytoplankton groups to chlorophyll a (chl a). Data were organized into station groups with similar pigment ratios using hierarchical cluster analyses (see 'Statistical analyses' below) of environmental variables and ratios of pigments to total accessory pigments (TAccp). The pigments included in the analysis are listed in Table 1. Three separate initial input matrices were developed and used for CHEMTAX analysis. The different subsets included (1) estuarine-inner shelf, (2) offshore surface slope waters, and (3) deep slope waters. From the cluster analysis results, we concluded that pigment patterns in midshelf waters bore characteristics of both inner shelf and slope waters. Initial ratios of phytoplankton groups at midshelf represented a combination of both inner shelf and slope water values. The haptophyte phytoplankton group was subdivided into haptophyte-6 (hapto-6) and haptophyte-8 (hapto-8) according to Zapata et al. (2004), and prasinophytes were divided into prasinophyte-I (pras-I) and prasinophyte-II (pras-II) after Schlüter et al. (2006). Optimization of the input pigment:chl a ratio matrix was achieved through the construction of a series of 60 different ratio matrices by multiplying each ratio of the initial matrix by a random function as described in Roy et al. (2011). The average of the best 6 output results (i.e. $10 \%, \mathrm{n}=6$ with smallest residual root mean square) was then run repeatedly in CHEMTAX until a stable ratio matrix was obtained (Latasa 2007). We acknowledge that the results of CHEMTAX analyses are an approximate representation of the phytoplankton taxa. Discrimination of taxa is sensitive to variation in pigment composition that can be influenced by several physiological and environmental factors (cf. Roy et al. 2011). Additionally, marker pigments are shared among different groups (Table 1), which can introduce ambiguity. Further information is provided about the choice of initial ratios for CHEMTAX analyses and final ratio matrices derived for each phytoplankton group and water mass regime in Table S1 in the Supplement at www.intres.com/articles/suppl/m521p031_supp.pdf.

Table 1. Major pigments/pigment groups and phytoplankton groups studied

\begin{tabular}{|c|c|c|c|}
\hline Abbrev. & Description & Formula & Taxonomic group \\
\hline $\operatorname{chl} a$ & Chlorophyll a & $\operatorname{chl} a=(\operatorname{chl} a+\operatorname{chl} a$-epimer $+\operatorname{chl} a$-allomer $)$ & Represents biomass in this study \\
\hline DVchla & Divinyl chlorophyll a & & Prochlorophytes (prochl) \\
\hline Tchl a & Total chlorophyll a & Tchl $a=\Sigma(\operatorname{chl} a+$ DVchl $a+$ chllide $-a)$ & Universal \\
\hline $\operatorname{chl} b$ & Chlorophyll $b$ & & Green algae (e.g. chlorophytes) \\
\hline DVchl $b$ & Divinyl chlorophyll $b$ & & Prochl \\
\hline Tchl $b$ & Total chlorophyll $b$ & Tchl $b=\Sigma(\operatorname{chl} b+\mathrm{DV} \operatorname{chl} b)$ & \\
\hline $\operatorname{chl} C_{2,1}$ & Chlorophyll $C_{2,1}$ & & Multiple \\
\hline $\operatorname{chl~} c_{3}$ & Chlorophyll $C_{3}$ & & $\begin{array}{l}\text { Haptophytes (hapto), diatoms } \\
\text { (diato), pelagophytes (pelago) }\end{array}$ \\
\hline $\begin{array}{l}\text { Tchl } C \\
\text { caro }\end{array}$ & $\begin{array}{l}\text { Total chlorophyll } C \\
\text { Carotenes }\end{array}$ & $\begin{array}{l}\text { Tchl } c=\Sigma\left(\operatorname{chl} c_{1}+\operatorname{chl} c_{2}+\operatorname{chl} c_{3}\right) \\
\operatorname{caro}=(\beta \beta-\operatorname{car}+\beta \varepsilon-\operatorname{car})\end{array}$ & \\
\hline allo & Alloxanthin & & Cryptophytes (crypto) \\
\hline $19^{\prime}$-but & 19'-butanoyloxyfucoxanthin & & Pelago, haptophytes (hapto) \\
\hline $19^{\prime}$-hex & 19'-hexanoyloxyfucoxanthin & & Hapto \\
\hline ddx & Diadinoxanthin & & Diato, hapto, pelago \\
\hline fuco & Fucoxanthin & & $\begin{array}{l}\text { Diato, hapto, some dinoflagellates } \\
\text { (dinofl) }\end{array}$ \\
\hline diato & Diatoxanthin & & Diato and various \\
\hline lut & Lutein & & Green algae \\
\hline neo & Neoxanthin & & Green algae \\
\hline viola & Violaxanthin & & Green algae \\
\hline peri & Peridinin & & Dinofl \\
\hline pras & Prasinoxanthin & & Prasinophytes \\
\hline zea & Zeaxanthin & & $\begin{array}{l}\text { Cyanobacteria (cyano), prochl \& } \\
\text { green algae }\end{array}$ \\
\hline PSC & Photosynthetic pigments & $\mathrm{PSC}=\Sigma\left(19^{\prime}\right.$-but + fuco $+19^{\prime}$-hex + peri $)$ & \\
\hline PPC & Photoprotective pigments & $\mathrm{PPC}=\Sigma($ allo + diad + ddx + zea + caro $)$ & \\
\hline TAсcр & Total accessory pigments & $\mathrm{TAccp}=\Sigma(\mathrm{PPC}+\mathrm{PSC}+\mathrm{Tchl} c+\mathrm{Tchl} b)$ & \\
\hline TEuk & Total eukaryotes & $\begin{array}{l}\text { TEuk }=\Sigma(\text { dinofl }+ \text { diato }+ \text { crypto }+ \text { hapto }+ \\
\text { chloro }+ \text { pelago })\end{array}$ & \\
\hline TProk & Total prokaryotes & TProk $=\Sigma($ cyano + prochl $)$ & \\
\hline
\end{tabular}




\section{Statistical analyses}

Hierarchal cluster analysis was carried out using SPSS v.20 software. City block distances were calculated using Ward's minimum variance method. Two separate analyses were performed. The first was to identify the different water types using $T, S$, chl $a$, SPM, and bathymetry (Fig. S1 in the Supplement). A second analysis examined natural groupings in phytoplankton pigments to confirm that pigment ratios were consistent within a water type (data not shown). The nonparametric Kruskal-Wallis test and Mann-Whitney $U$-test were used to ascertain differences among pigment concentrations, phytoplankton composition, and environmental variables for different sampling depths, periods and regions.

Principal component analysis (PCA) was applied separately to data from each of the different water types to access relationships between the taxonomic groups of phytoplankton and the environmental variables. Environmental variables included $T, S$, mixed layer depth $\left(Z_{\mathrm{m}}\right)$, stratification index $\left(N_{\mathrm{f}}\right)$, chl $a$, dissolved inorganic nitrogen (DIN, sum of $\mathrm{NO}_{3}+\mathrm{NO}_{2}+$ $\mathrm{NH}_{4}$ ) $, \mathrm{PO}_{4}, \mathrm{NH}_{4}$, and $\mathrm{SiO}_{3}$. In addition, sea surface currents were obtained from a physical circulation model (IASNFS; Ko 2003), and included eastward or zonal $(C-u)$ and northward or meridional $(C-v)$ vector components (units of $\mathrm{m} \mathrm{s}^{-1}$ ). Similarly, vector wind components for the eastward $(W-u)$ and northward $(W-v)$ directions $(3 \mathrm{~h}$ mean wind components at $10 \mathrm{~m}$ height in units of $\mathrm{m} \mathrm{s}^{-1}$ ) were obtained from NOGAPS (https://hycom.org/dataserver/nogaps). Weekly means of sea surface currents and sea surface winds were computed and used in the analysis. Relative abundance (fraction of chl a) of selected taxonomic groups including diatoms, cryptophytes, haptophytes, cyanobacteria, and prochlorophytes were included in the PCA analysis. These groups were selected because they represent the major taxa for this region.

\section{RESULTS}

\section{Spatio-temporal variability of water mass properties in the NGOM}

For each season, stations were grouped, based on cluster analysis of water mass properties $(T, S$, bathymetry, SPM, chl a), into 4 categories including estuarine, inner shelf, midshelf, and offshore regimes. In some cases, classification of stations as either estuarine or inner shelf differed among seasons, and for this reason, these 2 clusters were grouped together for some analyses. Samples collected during the different cruises showed marked regional and seasonal variability in physical and biogeochemical properties (Table 2). Temperature profiles were characterized by the existence of a seasonal thermocline at some stations during summer, at depths ranging from 10 to $15 \mathrm{~m}$ in inner shelf waters and 12 to $20 \mathrm{~m}$ in midshelf waters (Fig. S2 in the Supplement). Thermoclines were also evident at offshore (slope) stations, increasing in depth from shallowest during strongly stratified summer to deepest during completely mixed winter conditions (Fig. S2).

Mean $( \pm \mathrm{SD})$ salinities ranged from a low of $26.8 \pm$ 7.1 in inner shelf waters to $35.24 \pm 2.33$ offshore. Low salinities at offshore (slope) stations of less than 31 were observed to coincide with an offshore extension of the Mississippi River plume that occurred during July 2009, as has been previously described (Feng et al. 2012, Zhang et al. 2012). During this period, a low salinity surface lens $(28.9 \pm 1.31)$ was present at several south central slope stations. Salinities in offshore waters in spring 2010 were significantly ( $p<0.05$ ) lower than the seasonal average for all offshore stations (Table 2, and cf. Huang et al. 2013).

The variability in salinity and temperature reflected a combination of the influence of high freshwater discharge during the spring season (Fig. 2) and thermal stratification in summer, which in turn influenced $Z_{\mathrm{m}}$. Seasonal variations in $Z_{\mathrm{m}}$ were particularly prominent at midshelf and slope stations, with deepest $Z_{\mathrm{m}}$ observed in winter (Jan 2009) and spring 2010 (Table 2, Fig. 3a,b). During summer, mixed layer depths were relatively shallow at both midshelf (Table 2) and slope stations. The $N_{\mathrm{f}}$ was generally higher in estuarine and inner shelf waters and for all water types during summer (Fig. 3c, Table 2).

\section{Inorganic nutrients}

Spatial patterns in nutrient concentrations in the NGOM were characterized by strong cross-shelf gradients. Surface values of DIN and $\mathrm{SiO}_{3}$ were orders of magnitude higher in estuarine and inner shelf regions than in midshelf and offshore waters (Table 2), attributable to the high nutrient riverine inputs. Concentrations of DIN were relatively low in slope waters with the exception of the spring 2010 cruise, when concentrations were significantly higher $(\mathrm{p}<$ 0.05) compared to other periods (Table 2). The spring 2010 cruise occurred after a distinct peak in discharge of the Mississippi and Atchafalaya rivers in February 2010 (Fig. 2a); discharge levels of both 


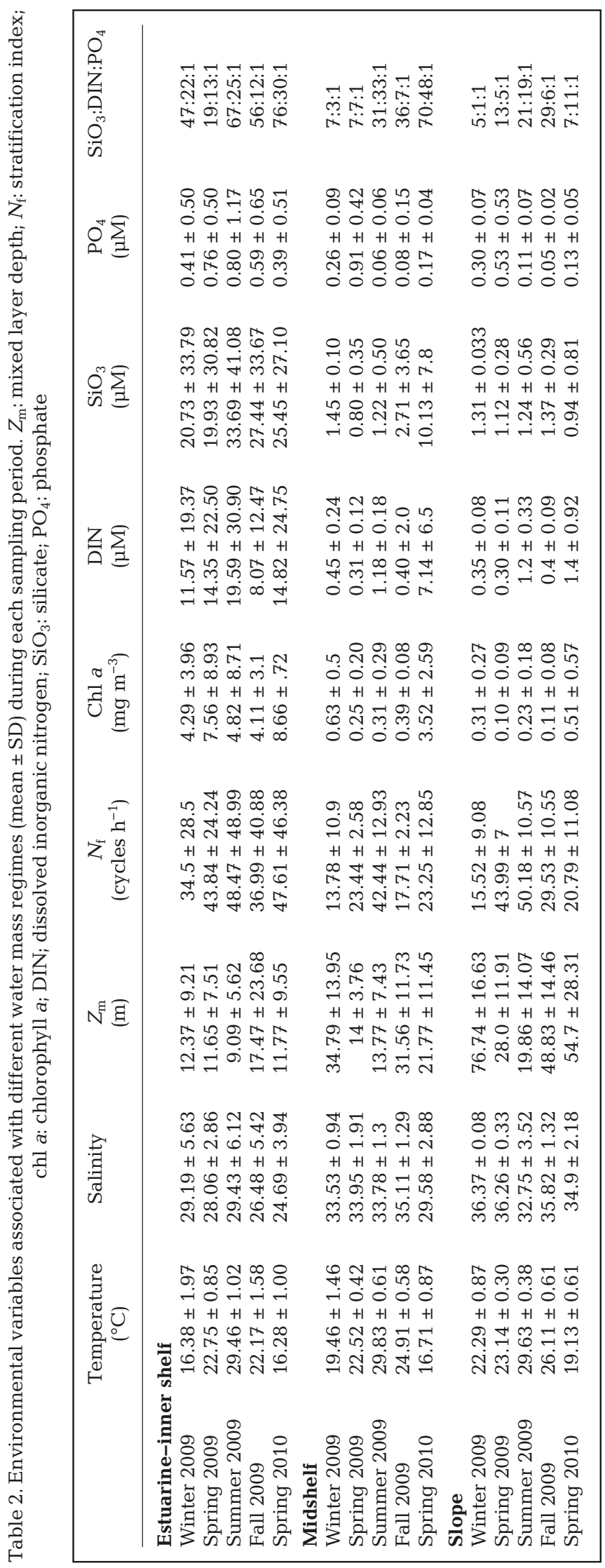

rivers were high at that time compared to the $5 \mathrm{yr}$ means (Fig. 2b).

An examination of nutrient ratios provided evidence for varying conditions of potential nutrient limitation as defined using the criteria of Dortch \& Whitledge (1992) and Justic et al. (1995). Most of the offshore stations (with the exception of spring 2010 and Mississippi plume-impacted stations in summer) were potentially limited by nitrogen based on observed DIN: $\mathrm{PO}_{4}$ ratios of $<10$, and $\mathrm{NO}_{3}+\mathrm{NO}_{2}$ concentrations $<1 \mu \mathrm{M}$ (data not shown). Additionally, potential P-limitation in estuarine and inner shelf waters was inferred from observations of both DIN: $\mathrm{PO}_{4}$ and $\mathrm{SiO}_{3}: \mathrm{PO}_{4}$ ratios $>22$ (Fig. 3e-h), and $\mathrm{PO}_{4}<0.2 \mu \mathrm{M}$ which was frequently observed during summer (Table 2). Potential S-limitation $\left(\mathrm{SiO}_{3}\right.$ :DIN ratios $<1$ and $\mathrm{SiO}_{3}$ values $<1 \mu \mathrm{M}$ ) was observed at several offshore stations during summer and spring 2010, and in midshelf during spring 2009. In general, $\mathrm{SiO}_{3}$ :DIN molar ratios were $>1$ in estuarine and inner shelf (Fig. 3e-h), an indication that $\mathrm{SiO}_{3}$ supplies were not limiting. $\mathrm{NH}_{4}$ concentrations in slope waters were high during fall $(0.31 \pm 0.09 \mu \mathrm{M})$, with highest values observed in the plume-impacted stations during summer $(0.72 \pm 0.40 \mu \mathrm{M})$.

\section{Phytoplankton pigment composition and taxonomic groups}

Strong cross-shelf gradients were evident in surface $\mathrm{chl} a$ and in pigment composition from estuarine and inner shelf regions to offshore (slope) stations (Fig. 4). CHEMTAX-derived phytoplankton community composition in estuarine and inner shelf water was primarily diatom-dominated (Fig. 5a), with diatoms accounting for $\sim 50$ to $65 \%$ of chl $a$ in winter and spring cruises (2009 and 2010) and $\sim 30$ to $46 \%$ during summer and fall. Multiple species of the diatoms Skeletonema, Pseudo-nitzschia and Thalassiosira dominated the estuarine and inner shelf waters. Fucoxanthin, a carotenoid characteristic of diatoms, was the dominant accessory pigment in the region (Fig. 4b), with high values reaching 1.8 to $5 \mathrm{mg} \mathrm{m}^{-3}$. Besides fucoxanthin, other important pigments included alloxanthin (a marker of cryptophytes) and chl $b$ (chlorophytes). Cryptophytes were the second major group, accounting for $\sim 20 \pm 5 \%$ of the chl $a_{\text {, }}$ while chlorophytes accounted for $\sim 6 \pm 7 \%$ of chl a. In stratified summer conditions (Table 2, Fig. 3c), the relative contribution of diatoms to chl a was significantly lower (Fig. 5a, p < 0.05) relative to other periods. In contrast, the cyanobacteria fraction in summer 

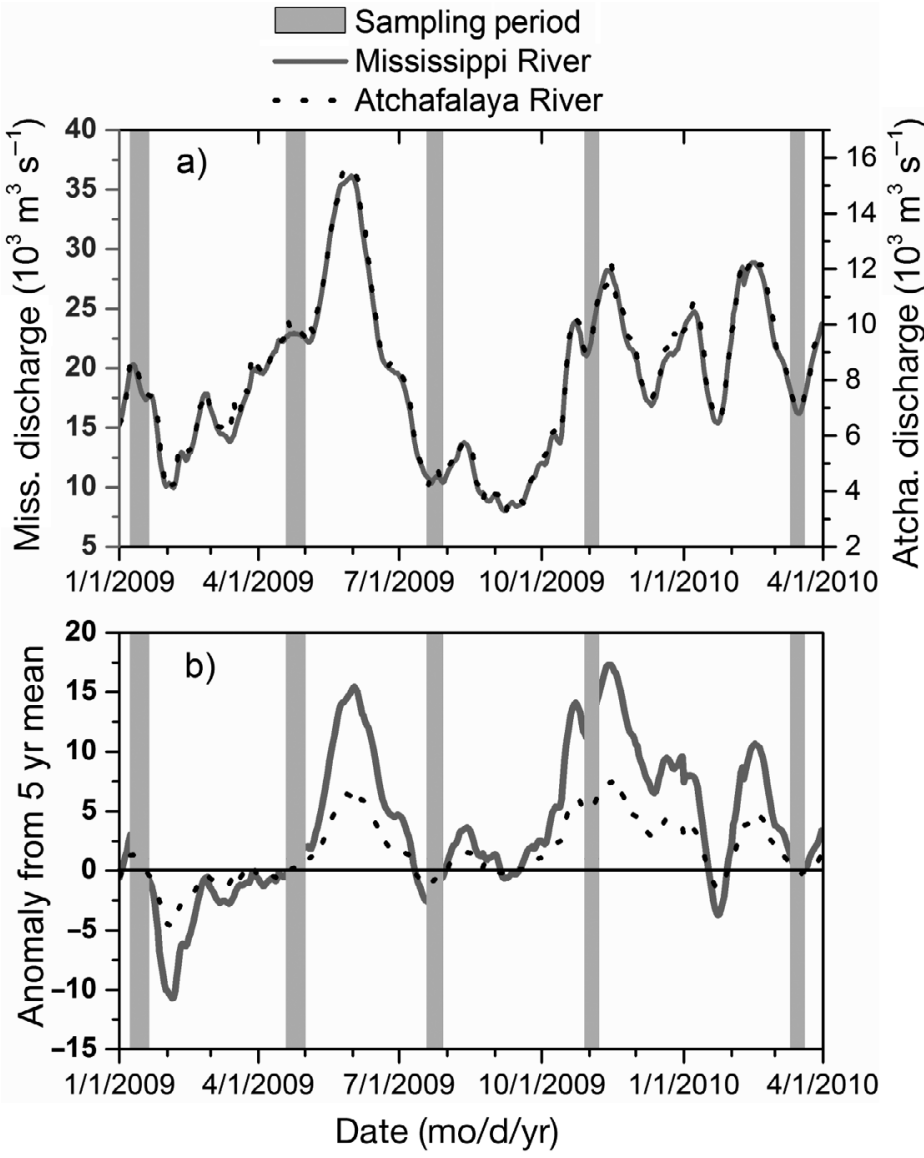

Fig. 2. (a) Mean daily discharge of the Mississippi (left axis) and the Atchafalaya (right axis) rivers from January 2009 to March 2010; (b) average discharge anomaly for the Mississippi and Atchafalaya rivers relative to the mean for the duration of the study

was significantly higher ( $\mathrm{p}<0.05$ ), occupying $\sim 30 \%$ of chl $a$ in comparison to an average of only 3 to $7 \%$ of chl a across all seasons. Trichodesmium tufts were observed by microscopy at several inner shelf stations during summer sampling, but it was not possible to assess its overall abundance relative to other cyanobacteria. With the exception of spring 2010 and summer, dinoflagellates along with prasinophytes and haptophytes accounted for a relatively small fraction (1.2 to $5.4 \%$ ) of chl a. Dinoflagellate contributions were $>10 \%$ of chl a in spring 2010 ; dinoflagellate genera observed by microscopy included Prorocentrum and some Gyrodinium during that cruise.

Midshelf waters represented the transitional zone between the inner shelf and the offshore with intermediate levels of chl a (Table 2, Fig. 4a). The phytoplankton community exhibited seasonal fluctuations, with diatoms accounting for $\sim 48$ and $\sim 64 \%$ of chl a during winter and spring 2010 respectively (Fig. 5b). Consistent with this observation, fucoxanthin con- centrations were higher ( 2 to 7 times) during spring 2010 (0.29 to $\left.0.91 \mathrm{mg} \mathrm{m}^{-3}\right)$ and winter $(0.09$ to $0.27 \mathrm{mg}$ $\mathrm{m}^{-3}$ ) than during other periods. The pennate diatom Pseudo-nitzschia was observed microscopically in several samples. Cyanobacteria were a relatively large fraction of chl a $(\sim 45 \%)$ during the summer in midshelf waters (Fig. 5b), with zeaxanthin being the dominant pigment (zeaxanthin:TAccp ranged between 30 and $45 \%$ ). Haptophytes were important at midshelf, and the ratio of 19'-hexanoyloxyfucoxanthin:TAccp was higher by an order of magnitude in midshelf as compared to inner shelf waters (Fig. 4b). The non-calcifying haptophytes (hapto-8) were relatively important $(\sim 13 \%$ of chl a) during the nonstratified periods (winter and spring 2010). Phaeocystis, a representative of the hapto-8 group, was also observed microscopically. Hapto-6, the calcifying group ( $14 \%$ of chl a), was relatively more abundant during the stratified periods. Under the partially stratified conditions during fall in midshelf waters, cyanobacteria (22\%) and prochlorophytes (16\%) were the major phytoplankton groups as supported by the presence of diagnostic markers including zeaxanthin and divinyl chlorophyll a (DVchla) and divinyl chlorophyll $b(\mathrm{DV}$ chl $b)$. Average DVchla:TAccp ratios during fall were $\sim 2.5$ times higher than that of other periods. The midshelf community in subsurface waters (<50 m) mainly consisted of diatoms (16 to 65\%) and hapto-8 (10 to $30 \%)$. Varying contributions were observed for pras-I ( 7 to $20 \%$ ) and cyanobacteria (0 to $23 \%$ ) along with some contributions from diatoms and haptophytes.

Chl a concentrations were relatively low in offshore (slope) waters (means were 30 to $75 \%$ lower than the shelf stations), and cyanobacteria mainly dominated $(42.8 \pm 16.9 \%$ of $\mathrm{chl}$ a). Zeaxanthin along with DVchla were the major pigments in surface offshore waters (Fig. 4b), and occasionally DVchlb was observed. The only exception was spring 2010, when relatively high values of chl a were observed $(0.25$ to $1.28 \mathrm{mg} \mathrm{m}^{-3}$ ) and zeaxanthin:TAccp concentrations were substantially lower than other periods (Table S2 in the Supplement). Prochlorophytes were also consistently observed (average $20.29 \pm 11.8 \%$ of $\mathrm{chl}$ a) in offshore waters except in spring 2010. The highest prochlorophyte abundance was observed during fall, comprising $\sim 32 \%$ of chl a. Haptophytes were also common, contributing on average $25 \pm 9 \%$ of chl $a$, and ratios of 19'-hexanoyloxyfucoxanthin:TAccp varied between 10 and $20 \%$. Among the haptophytes, hapto6 was more prevalent, averaging $19 \pm 8 \%$ of chl a.

Notable changes in phytoplankton communities were observed in association with offshore exten- 

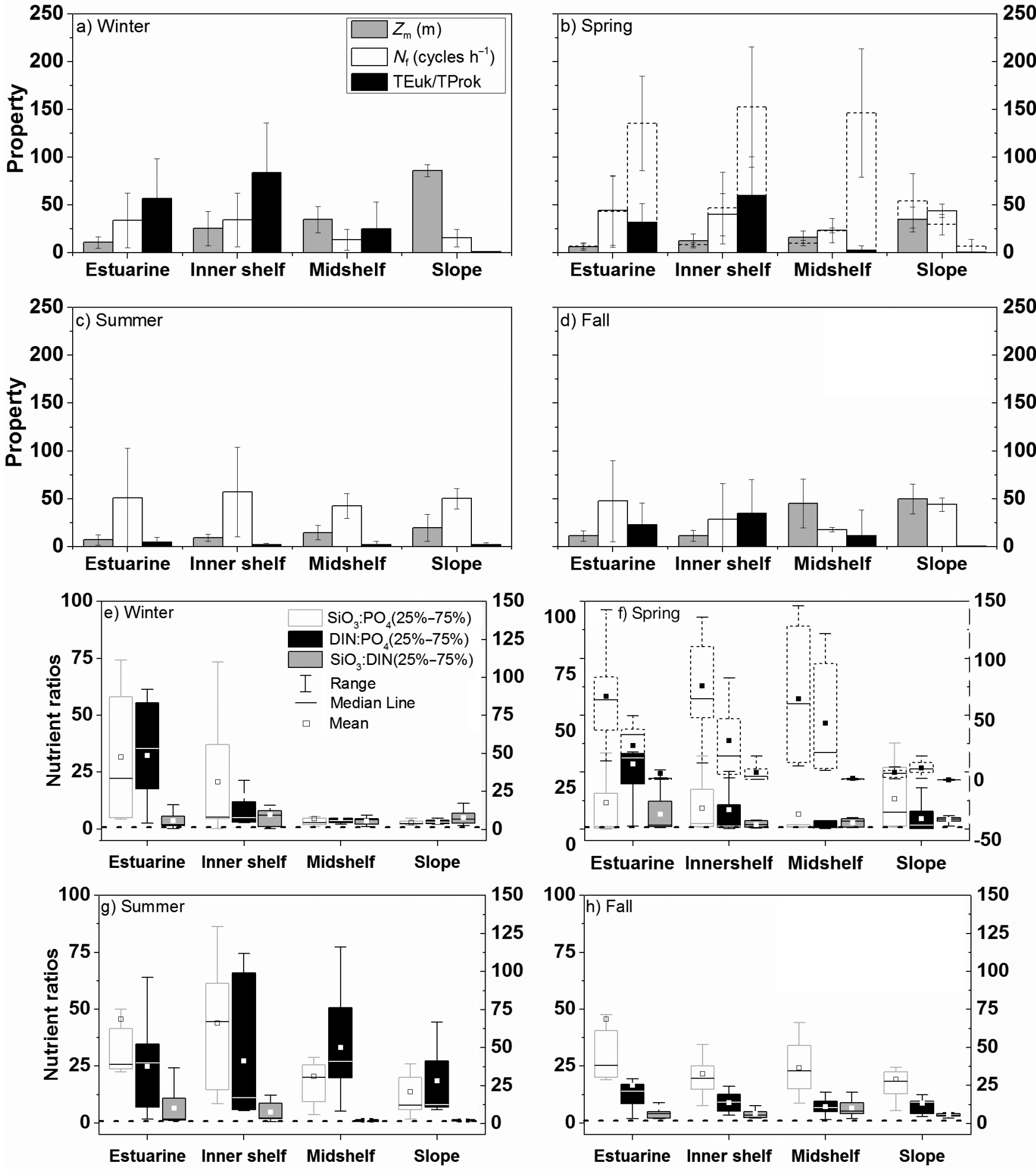

Fig. 3. Seasonal variations in $(\mathrm{a}-\mathrm{d})$ mixed layer depths $\left(Z_{\mathrm{m}}\right)$, stratification index $\left(N_{\mathrm{f}}\right)$, ratios of total eukaryote (TEuk):total prokaryote $($ TProk), and $(\mathrm{e}-\mathrm{h})$ nutrient ratios. TEuk $=$ (dinoflagellates + diatoms + cryptophytes + haptophytes + chlorophytes + pelagophytes $)_{i}$ TProk = (cyanobacteria + prochlorophytes). Dashed bars in (b) and dashed box and whiskers in (f) represent

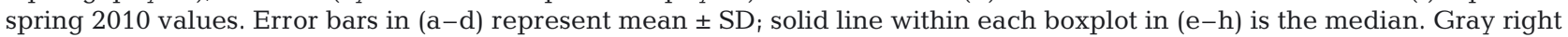
axes in $(e, g, h)$ represent $\mathrm{SiO}_{3}: \mathrm{PO}_{4}$ and $\mathrm{SiO}_{3}: \mathrm{DIN}$ ratios; dashed right axis in (f) represents spring 2010 values (offset for clarity). Dashed horizontal lines in $(\mathrm{e}-\mathrm{h})$ correspond to a ratio of 1 (not shown for spring 2010). Key in (a) applies to panels (a-d); key in

(e) applies to panels $(\mathrm{e}-\mathrm{h})$ 

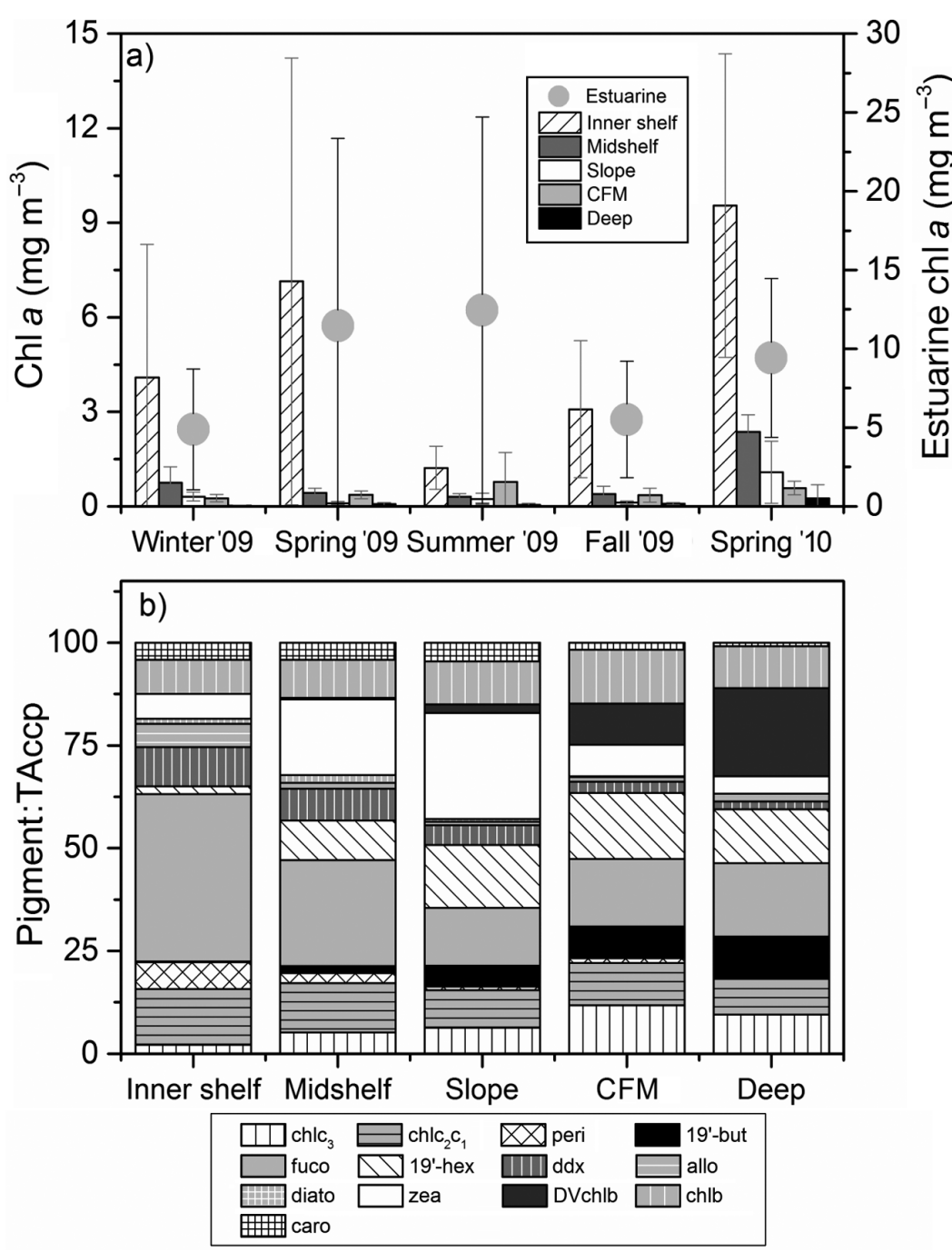

Fig. 4. Mean $\pm \mathrm{SD}$ of (a) chlorophyll $\mathrm{a}(\mathrm{chl} a)$ and (b) ratios of pigments relative to total accessory pigments (TAccp) for the different regimes in the northern Gulf of Mexico (NGOM). Estuarine chl a concentrations are represented on the right axis in the top panel. CFM: chlorophyll fluorescence maximum; see Table 1 for other abbreviations used in the key

sions of Mississippi plume waters during summer and spring 2010. During the summer 2009 cruise, low salinity plume water was detected at several offshore stations (Stns a5, a6, b4, b5, and c4 in Fig. 1). Diatoms dominated $(\sim 58 \%)$ the low salinity $(<31)$, high $\mathrm{chl} a$ (0.29 to $0.8 \mathrm{mg} \mathrm{m}^{-3}$ ) plume stations in comparison to the non-plume stations, where the diatom fraction averaged $\sim 4 \%$ (Table 3 ). Fucoxanthin concentrations at plume-impacted stations were about 30 times greater than the non-plume slope stations (Table 3). The diatom species Skeletonema and Phaeodactylum were identified in water samples collected at some of the plume-affected offshore stations. Cyanobacteria (including Trichodesmium observed microscopically) dominated the non-plume stations (Table 3). Another offshore extension of river-influenced waters occurred in spring 2010. Strong winds from the north and northwest driven by the presence of large, low pressure systems over North America along with record high river discharge from the Mississippi-Atchafalaya river system resulted in large amounts of nutrients transported onto the shelf (Huang et al. 2013). Low salinity $(\leq 34.7)$ lenses (depths of 1.5 to $2.25 \mathrm{~m}$ ) high in chl $a$ and nutrients were detected at some offshore stations during the study (data not shown). These conditions coincided with relatively high diatom abundance (Table 3) in plume-influenced $(S>31)$ offshore waters. Small centric diatoms (Thalassiosira sp. and Chaetoceros sp.), and larger species of Rhizosolenia sp. and Guinardia sp. were prevalent in microscopic observations. Besides diatoms, haptophytes, dinoflagellates, cryptophytes and prasinophytes were also present based on CHEMTAX analysis (Fig. 5c). Dinoflagellates observed microscopically mainly included Scrippsiella sp. and Prorocentrum sp.

We observed a general pattern of increasing mixed layer depth and decreasing ratios of total eukaryote to total prokaryote chl a (TEuk:TProk; Fig. 3a-d) from estuarine and inner shelf to midshelf to slope waters. In addition, the highest ratios of TEuk:TProk were observed in winter and spring. Spring 2010 represented a period of exceptionally high TEuk:TProk ratios (Fig. 3b).

A subsurface CFM was a prominent feature in slope waters, with chl $a$ values at the CFM feature in some cases 3 to 8 times higher than at the surface, particularly in spring and summer 2009 (Fig. 4a). The CFM feature was absent during winter, and was replaced by a surface layer maximum during spring 2010 (Fig. S2). Phytoplankton communities observed in offshore CFM and deep sample populations were different from those in surface waters. A major portion of the CFM and deep communities was comprised of prochlorophytes, on average accounting for between 18 and $58 \%$ of chl a (Fig. 6a) and 33 to $61 \%$ at greater depths (100 to 150 m; Fig. 6b). In general, DVchla and DVchlb levels increased with depth and the ratio of DVchlb:DVchla increased from a range of $0.1-0.2$ in surface waters to $1-4.5$ for depths at or below the CFM. There was also seasonal variability 

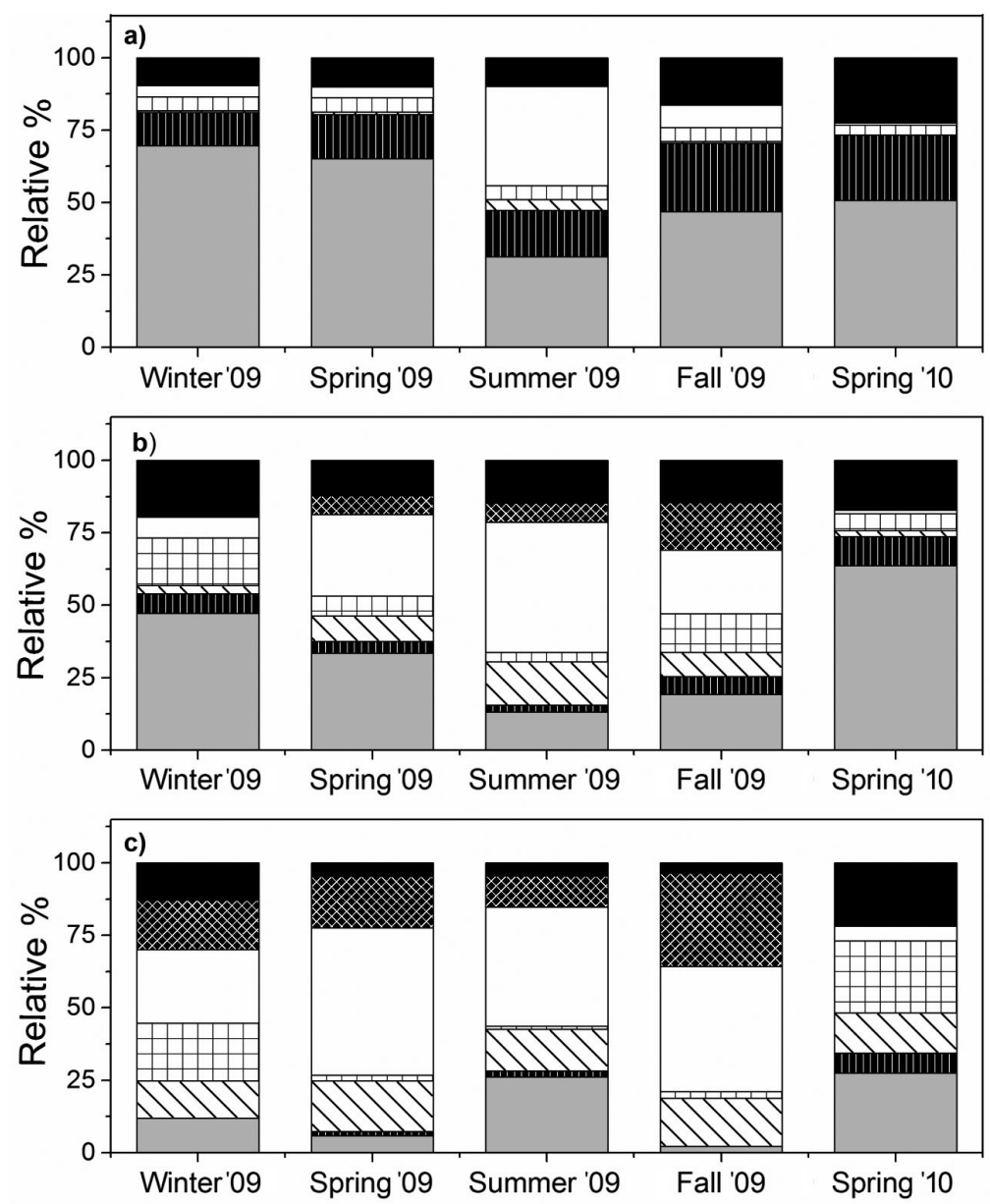

\begin{tabular}{|c|c|}
\hline Diato & Crypto $\triangle \nabla$ Hapto-6 $\square$ Hapto-8 \\
\hline Cyano & Prochl $\quad$ Others \\
\hline
\end{tabular}

Fig. 5. Relative percentages of chlorophyll a (chl a) as determined using CHEMTAX attributed to major phytoplankton groups in (a) estuarine and inner shelf, (b) midshelf and (c) slope waters for the different cruise periods. The 'Others' category includes dinoflagellate, chlorophyte, prasinophyte and pelagophyte taxa; see Table 1 for other abbreviations used in the key

in the prochlorophyte contribution to $\mathrm{chl} a$, which peaked in fall and was minimal in spring 2010. In contrast to other periods, a more evenly mixed assemblage was observed in deep offshore populations during spring 2010, with representation from diatoms $(\sim 30 \%)$, hapto-8 $(19 \%)$, and cyanobacteria $(\sim 5 \%)$ along with smaller contributions from pelagophytes and prasinophytes (Fig. 6b). Both pelagophytes and prasinophytes were consistently observed in CFM and deeper waters during all cruise periods (Fig. 6) and were present in higher proportions than that of surface offshore populations (Table S3 in the Supplement). This was further supported by higher ratios of prasinoxanthin:TAccp and 19'-butanoyloxyfucoxanthin:TAccp (Fig. 4b, Table S2) in the deeper samples.

\section{Multivariate analysis}

Relationships among phytoplankton community composition and environmental variables across the different hydrographic regimes and cruise periods were examined using PCA (Fig. 7, Table 4). In general, the first 2 principal components accounted for 58 to $60 \%$ of the total variance. Variable weightings (i.e. loadings) for the first component (PC1) were highest for salinity along with $\mathrm{NO}_{3}+\mathrm{NO}_{2}, \mathrm{SiO}_{3}$, and chl a. PC1 was thus considered to represent the influence of freshwater inputs and associated terrestrial materials. Significant loadings for PC2 were positive for temperature and negative for $Z_{\mathrm{m}}$, and consequently PC2 was interpreted as an index of surface warming and stratification. This view was reinforced by the positive relationship of $N_{\mathrm{f}}$ with PC2 in midshelf and offshore waters. Additionally, the positive relationship of $W$ - $v$ to PC2 in midshelf and offshore waters was consistent with shoreward movement of warm, offshore waters. In contrast, $W$ - $u$ was positively related with PC1 in midshelf and offshore waters (Table 4), and such wind patterns would tend to be associated with offshore or eastward distribution of river outflow.

Further examination of the principal components (Fig. 7, Table 4) was useful in characterizing relation-

Table 3. Salinity and pigment concentrations (mean $\pm \mathrm{SD}$ ) at plume-impacted and non-plume slope (offshore) stations

\begin{tabular}{|c|c|c|c|c|c|c|}
\hline Station & Salinity & $\begin{array}{c}\mathrm{Chl} \mathrm{a} \\
\left(\mathrm{mg} \mathrm{m}^{-3}\right)\end{array}$ & $\begin{array}{l}\text { Fucoxanthin } \\
\left(\mathrm{mg} \mathrm{m}^{-3}\right)\end{array}$ & $\begin{array}{l}\text { Zeaxanthin } \\
\quad\left(\mathrm{mg} \mathrm{m}^{-3}\right)\end{array}$ & $\begin{array}{l}\text { Diatom } \\
(\%)\end{array}$ & $\begin{array}{c}\text { Cyanobacteria } \\
(\%)\end{array}$ \\
\hline Typical slope & $36.07 \pm 0.95$ & $0.146 \pm 0.08$ & $0.011 \pm 0.01$ & $0.047 \pm 0.016$ & $6.66 \pm 8.05$ & $40.63 \pm 10.76$ \\
\hline Plume (July 2009) & $28.9 \pm 1.31$ & $0.39 \pm 0.181$ & $0.153 \pm 0.124$ & $0.041 \pm 0.009$ & $58.9 \pm 21.4$ & $23.4 \pm 14.4$ \\
\hline Non-plume (July 2009) & $34.9 \pm 1.75$ & $0.125 \pm 0.041$ & $0.005 \pm 0.005$ & $0.057 \pm 0.047$ & $4.2 \pm 4.7$ & $56.3 \pm 8.9$ \\
\hline Plume (March 2010) & $34.2 \pm 2.48$ & $1.58 \pm 1.24$ & $0.122 \pm 0.103$ & $0.017 \pm 0.012$ & $26.15 \pm 19.6$ & $5.09 \pm 6.03$ \\
\hline
\end{tabular}



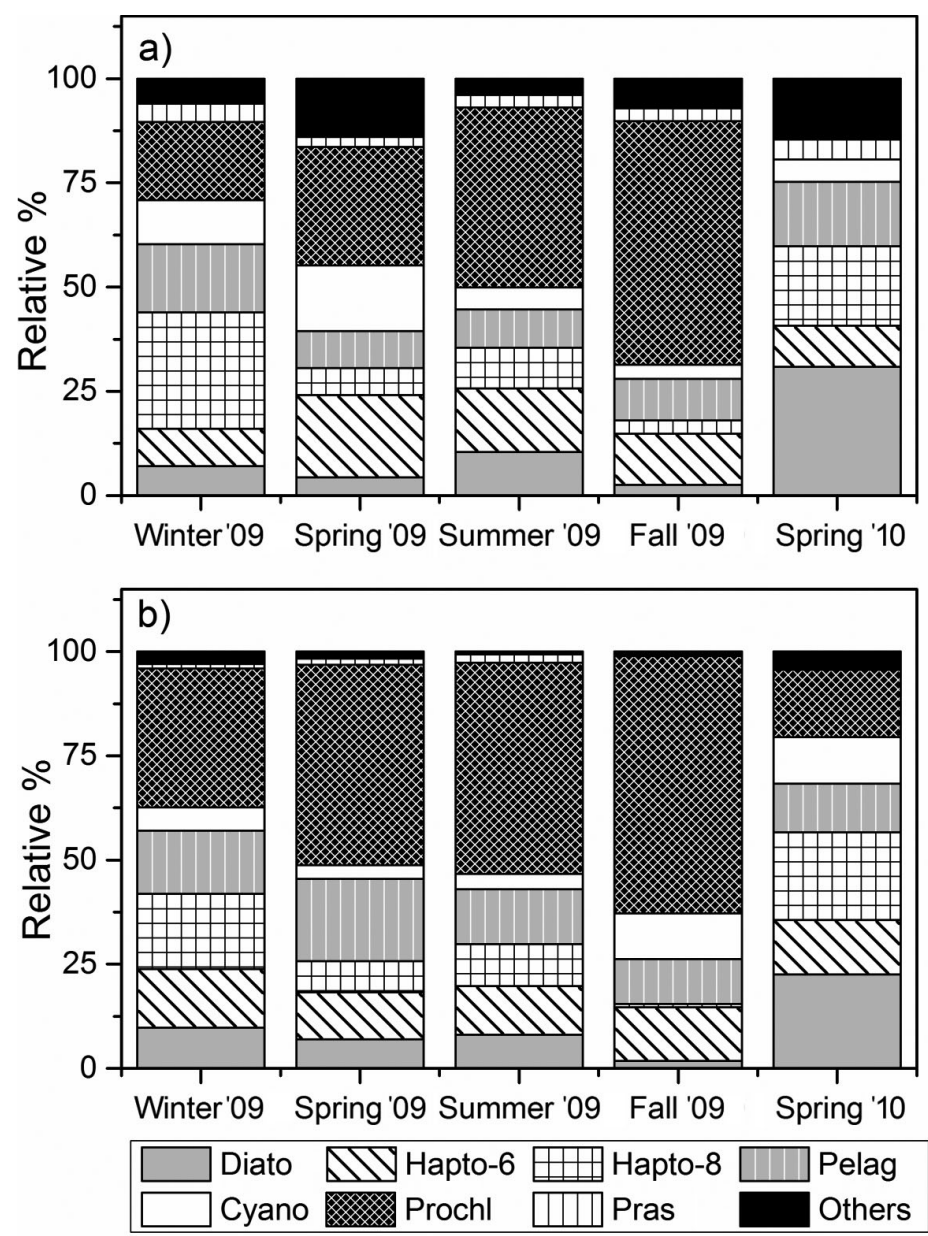

Fig. 6. Relative percentages of chlorophyll a (chl a) as determined using CHEMTAX attributed to (a) depths of the chlorophyll fluorescence maximum (CFM) and (b) deep waters for the different cruise periods. The 'Others' category includes dinoflagellate, cryptophyte and chlorophyte taxa; see Table 1 for other abbreviations used in the key input data, and loadings for chl a fractions of cryptophytes and diatoms were relatively high and positive, while cyanophyte, haptophyte and prochlorophyte loadings were negative (Fig. 7b,c; also see Table S4 in the Supplement). This was an indication that the relative abundance of taxa was related to river influence even at these midshelf and slope locations.

\section{DISCUSSION}

Our initial guiding question was this: What are the important environmental variables influencing phytoplankton dynamics in the Mississippi-Atchafalaya river-influenced margin of the NGOM? We addressed this question by considering 4 distinct phytoplankton regimes: (1) estuarine and inner shelf regimes dominated by diatoms, cryptophytes and cyanobacteria; (2) a mixed assemblage in the midshelf regime; (3) an oceanic regime at the slope mainly dominated by cyanobacteria, prochlorophytes and hapto-6; and (4) CFM and deep water regimes dominated by pelagophytes, haptophytes, prochlorophytes and cyanobacteria. While such groups have been previously characterized in this region, prior studies were limited in spatial extent and in the range of environmental variables potentially influencing the seasonal distribution and abundance of the phytoplankton groups in the NGOM. Here, we consider each of the regimes and discuss the relationships between environmental factors and phytoplankton taxonomic composition.

\section{Estuarine and inner shelf}

conditions in the different water mass types. In estuarine and inner shelf regimes, PC1 accounted for $\sim 39 \%$ of the total variability in the input data and, as previously noted, was an indication of freshwater influence on environmental conditions (positive loadings for nutrients and chl $a$, and negative loadings for salinity; Fig. 7a). The cryptophyte fraction of chl a was positively correlated $\left(\mathrm{r}^{2}=0.35, \mathrm{p}<0.05\right)$ with PC1 while the cyanobacteria and haptophyte fractions were negatively correlated $\left(\mathrm{r}^{2}=0.25\right.$ and 0.16 , respectively, $\mathrm{p}<0.05)$. The cyanobacterial fraction of total chl a was positively correlated with PC2 $\left(\mathrm{r}^{2}=\right.$ 0.47, $\mathrm{p}<0.05$ ), while diatom and cryptophyte fractions were negatively correlated $\left(\mathrm{r}^{2}=0.21\right.$ and 0.09 , respectively). In midshelf and slope regimes, PC1 accounted for 37 to $38 \%$ of total variability in the
Diatoms represented the largest fraction of chl a $(>50 \%)$ in NGOM estuarine and inner shelf waters along with important contributions from cryptophytes, cyanobacteria and chlorophytes. Seasonal variability was evident as we observed lower diatom fractions in stratified summer conditions (Fig. 5a), as has been previously reported (Schaeffer et al. 2012). Nutrient delivery from the Mississippi and Atchafalaya rivers into the inner shelf has been suggested to play a significant role in diatom dominance (Dortch \& Whitledge 1992, Lohrenz et al. 1999). In addition, energetic systems (e.g. estuarine and inner shelf) have been argued to favor large-celled phytoplankton such as diatoms (Margalef 1978). Crypto- 

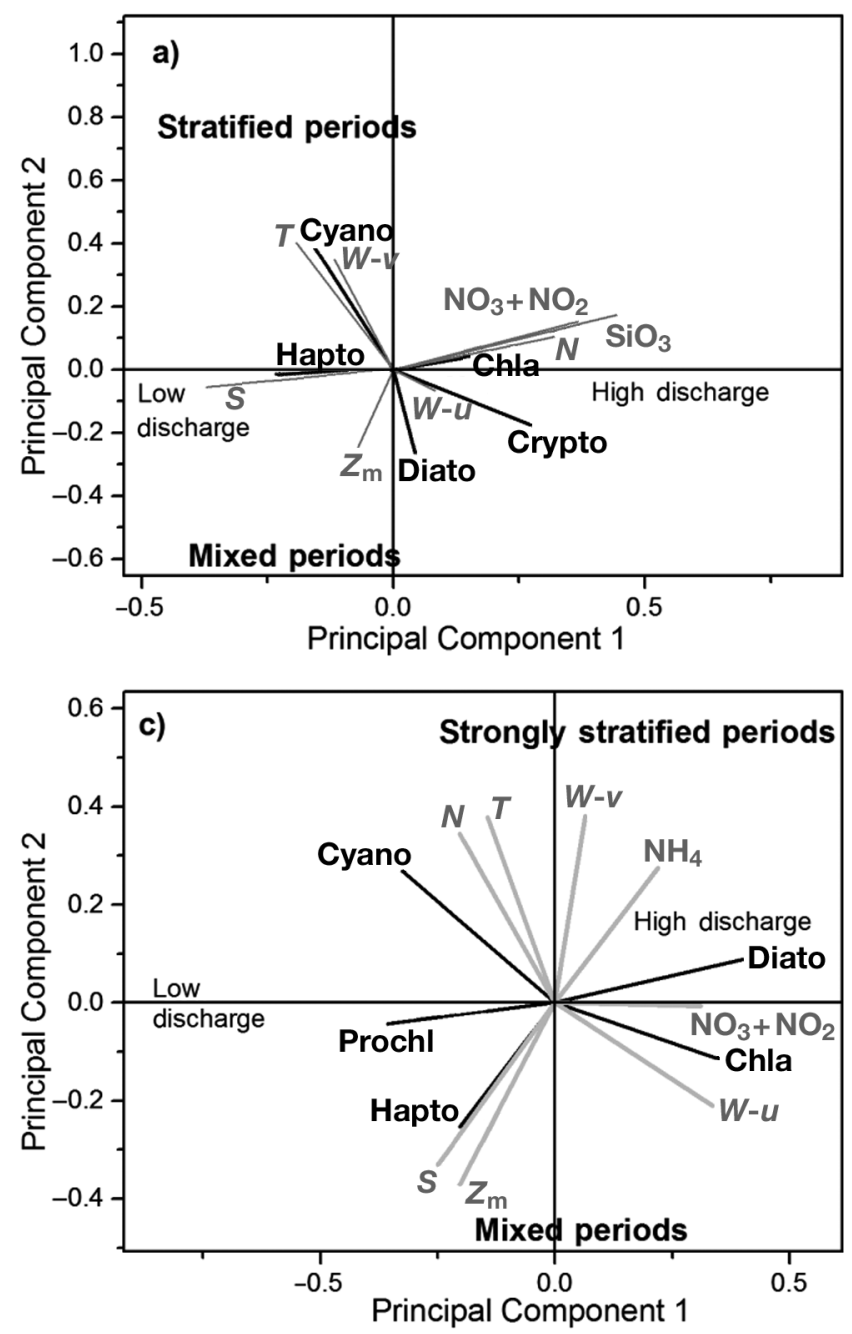

phytes and chlorophytes also were present in low salinity (i.e. <30) waters, with cryptophytes particularly common $(20 \%)$ in estuarine and inner shelf locations.

In contrast to diatoms, contributions by cyanobacteria were prominent in inner shelf waters during summer (stratified and nutrient-limited conditions; mean DIN: $\mathrm{PO}_{4}=25 \pm 20$ and mean $\mathrm{SiO}_{3}: \mathrm{DIN}=6 \pm 8$ ) and, to a smaller extent, during weakly stratified fall conditions (Fig. 5a). Cyanobacterial abundance has been shown to increase under warmer water temperatures (Li 1998) and lower discharge conditions (Paerl 1996), consistent with our findings (PCA results in Fig. 7, Table 4) and those of several previous studies in the inner shelf of the NGOM (Schaeffer et al. 2012). Increased cyanobacterial fraction of total chl a during summer may also be related to an ability to overcome phosphate limitation by utilizing dissolved organic phosphorous through increased alkaline phosphatase activity (Li et al. 1998). We ob-

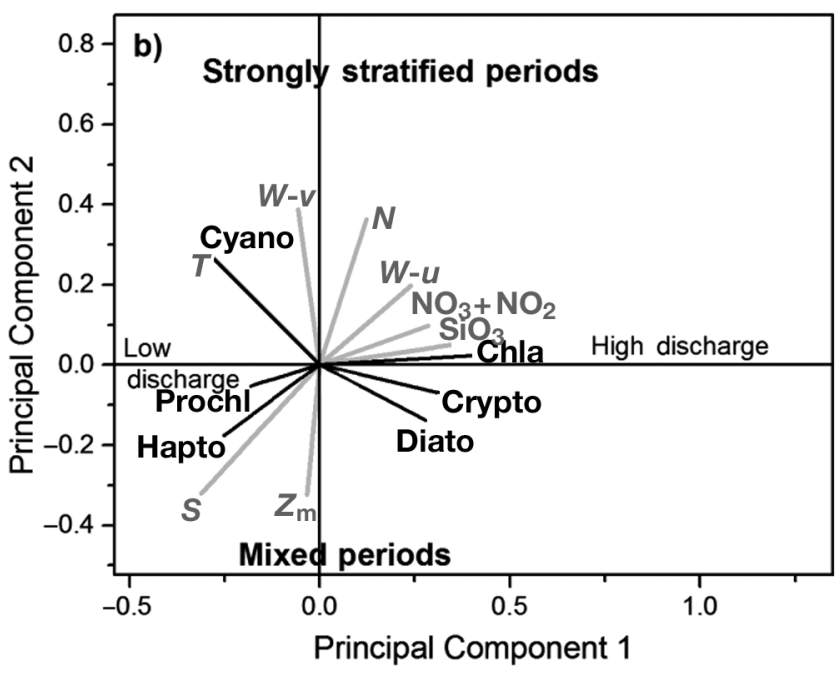

Fig. 7. Principal component analysis (PCA) biplots for different regimes including (a) estuarine and inner shelf, (b) midshelf and (c) slope. Gray lines: vector loadings (i.e. weightings) for the environmental variables; black lines: taxonomic groups. Vector length corresponds to magnitude of loading. Light gray annotation corresponds to environmental variables: $T$ (temperature), $S$ (salinity), $Z_{\mathrm{m}}$ (mixed layer depth), $N$ (Brunt-Väisälä frequency), $W-V$ (northward wind direction), $W-u$ (eastward wind direction), $\mathrm{SiO}_{3}$ (silicate), $\mathrm{NO}_{3}$ (nitrate), $\mathrm{NO}_{2}$ (nitrite), $\mathrm{NH}_{4}$ (ammonium); black annotations denote selected phytoplankton taxa: diatoms (diato), cryptophytes (crypto), haptophytes (hapto), cyanobacteria (cyano), and prochlorophytes (prochl)

served potential P-limitation in more than $30 \%$ of the inner shelf stations during the summer (July 2009) sampling period, and phosphate limitation and high alkaline phosphatase activity has been widely observed in the NGOM after high river discharge in late spring and summer months (Sylvan et al. 2006).

\section{Midshelf}

The midshelf region is a transitional zone between inner shelf and offshore waters. The phytoplankton community was mixed (Fig. 5b), with diatoms, cyanobacteria, haptophytes and prochlorophytes being the major contributing groups along with varying contributions from cryptophytes and other eukaryotic groups. Midshelf phytoplankton taxonomic composition was related to seasonal warming and stratification as well as river influence. Diatoms dominated in mixed winter conditions and during spring 2010 
Table 4. Correlation coefficients (r) of input variables for the first 2 principal components for each water mass type. Numbers in bold denote significant correlations $(\mathrm{p}<0.05)$ of variables with the given principal component. $\mathrm{NO}_{3}:$ nitrate; $\mathrm{NO}_{2}:$ nitrite; $_{\mathrm{SiO}}$ : silicate; $\mathrm{PO}_{4}$ : phosphate; $\mathrm{NH}_{4}$ : ammonium; $Z_{\mathrm{m}}$ : mixed layer depth; $C$-u: eastward sea surface current; $C$ - $v$ : northward sea surface current; $W$ - $u$ : eastward wind component; $W$ - $v$ : northward wind component; $N_{\mathrm{f}}$ : stratification index; diato: diatoms; crypto: cryptophytes; hapto: haptophytes; cyano: cyanobacteria; pelag: pelagophytes; prochl: prochlorophytes

\begin{tabular}{|c|c|c|c|c|c|c|}
\hline \multirow{2}{*}{$\begin{array}{l}\text { Correlation } \\
\text { coefficients (r) }\end{array}$} & \multicolumn{2}{|c|}{ Estuarine and inner shelf $(\mathrm{df}=88)$} & \multicolumn{2}{|c|}{ Midshelf $(\mathrm{df}=48)$} & \multicolumn{2}{|c|}{ Offshore (slope) $(\mathrm{df}=64)$} \\
\hline & PC1 (38.47\%) & PC2 (19.30\%) & PC1 $(36.68 \%)$ & PC2 $(20.13 \%)$ & PC1 $(38.04 \%)$ & PC2 $(20.57 \%)$ \\
\hline Salinity $(S)$ & -0.81 & -0.9 & -0.74 & -0.59 & -0.55 & -0.61 \\
\hline Temperature $(T)$ & -0.42 & 0.72 & -0.67 & 0.5 & -0.31 & 0.69 \\
\hline $\mathrm{NO}_{3}+\mathrm{NO}_{2}$ & 0.81 & 0.27 & 0.68 & 0.18 & 0.67 & 0.01 \\
\hline $\mathrm{SiO}_{3}$ & 0.9 & 0.28 & 0.81 & 0.09 & 0.1 & 0.2 \\
\hline $\mathrm{PO}_{4}$ & 0.68 & 0.27 & -0.27 & -0.24 & 0.25 & 0.07 \\
\hline $\mathrm{NH}_{4}$ & 0.64 & 0.31 & 0.17 & 0.58 & 0.47 & 0.5 \\
\hline$Z_{\mathrm{m}}$ & -0.29 & -0.36 & -0.08 & -0.6 & -0.44 & -0.68 \\
\hline$C-u$ & -0.23 & 0.63 & -0.37 & 0.41 & -0.16 & 0.36 \\
\hline$C-V$ & 0.27 & -0.58 & 0.06 & -0.28 & 0.02 & -0.23 \\
\hline$W-u$ & 0.18 & -0.12 & 0.57 & 0.36 & 0.73 & -0.39 \\
\hline$W-V$ & -0.25 & 0.63 & -0.13 & 0.72 & -0.14 & 0.7 \\
\hline$N_{\mathrm{f}}$ & 0.7 & 0.18 & 0.29 & 0.66 & -0.44 & 0.64 \\
\hline Chl a & 0.3 & 0.06 & 0.95 & 0.04 & 0.75 & -0.2 \\
\hline Diato & 0.19 & -0.47 & 0.66 & -0.25 & 0.68 & 0.16 \\
\hline Crypto & 0.59 & -0.31 & 0.73 & -0.12 & 0.076 & -0.067 \\
\hline Hapto & -0.51 & -0.02 & -0.6 & 0.06 & -0.44 & -0.46 \\
\hline Cyano & -0.33 & 0.68 & -0.65 & 0.48 & -0.71 & 0.49 \\
\hline Pelag & NA & NA & NA & NA & NA & NA \\
\hline Prochl & NA & NA & -0.43 & -0.09 & -0.78 & -0.08 \\
\hline
\end{tabular}

when the river influence extended over a large region of the shelf, while cyanobacteria dominated under stratified summer conditions (Figs. $5 b$ \& $7 b$ ). Significant $(\mathrm{p}<0.05)$ negative correlations between DIN: $\mathrm{PO}_{4}$ and $\mathrm{SiO}_{3}: \mathrm{DIN}$ existed with cyanobacteria and haptophyte groups. However, the coefficient of determination was small $\left(\mathrm{r}^{2}\right.$ ranged between 0.3 and 0.4). Our observations of the presence of 'mixed assemblages' at intermediate chl a levels (Fig. 4a, Table 2) is consistent with patterns inferred by Jolliff et al. (2008) based on satellite observations.

\section{Slope}

Picoplanktonic cyanobacteria and prochlorophytes along with haptophytes (hapto-6 and hapto-8) were relatively abundant in low nutrient slope (offshore) waters. These results are in agreement with previous studies in the NGOM (Lambert et al. 1999, Qian et al. 2003) as well as studies in subtropical oceanic waters (Gibb et al. 2001). Our findings confirmed the consistent presence of haptophytes in offshore waters of the NGOM as reported in prior studies. However, the haptophyte fraction of total chl $a$ in this study $(25 \pm$ $9 \%$ ) was less than the maximum values of $>35$ and $42 \%$ reported by Lambert et al. (1999) and Qian et al. (2003), respectively. The apparent difference may be due to the use of different approaches in determining the relative contribution of each phytoplankton group.

The phytoplankton community composition in NGOM slope waters was strongly related to MLDs and water column stratification (Fig. 3). Deeper mixed layers in winter 2009 and spring 2010 (Table 1, Fig. 3a,b) were accompanied by higher relative abundances of haptophytes (Fig. 5c) and other eukaryotes, mainly pelagophytes and prasinophytes relative to prokaryotes, which suggests better adaptive ability of these smaller eukaryotes in highly dynamic environments (Lindell \& Post 1995, Steinberg et al. 2001). Cyanobacteria and prochlorophytes occupied a major proportion of the community and hapto-6 was the dominant eukaryote (Fig. 5c). The hapto-6 group (e.g. Emiliania huxleyi) is known to flourish under nutrient-limited, stratified oceanic conditions. Prochlorophytes have also been found to favor stratified and nutrient-limited conditions (Bouman et al. 2006) in the subtropical ocean. Such was not so apparent in the NGOM, at least for the surface waters. Cyanobacteria (including Trichodesmium) dominated the surface slope waters under strongly stratified conditions (summer and spring 2009; Figs. 3 \& 5c). A potential explanation for the 
relatively low abundance of prochlorophytes in the offshore surface waters during spring and summer could be their susceptibility to UV radiation, as found in some studies (e.g. Sommaruga et al. 2005). Higher relative abundances of prochlorophytes in fall may have been related to their ability to efficiently use $\mathrm{NH}_{4}$ as an alternate resource (Moore et al. 2002). High surface $\mathrm{NH}_{4}$ concentrations $\left(\mathrm{NO}_{3}+\mathrm{NO}_{2}: \mathrm{NH}_{4}=\right.$ $0.3)$ and low DIN: $\mathrm{PO}_{4}(<10)$ ratios were observed during that period.

\section{CFM and deep water}

Stratification and mixing conditions also appeared to be factors influencing phytoplankton CFM communities. Strong stratification, particularly during summer and spring 2009 (and occasionally in fall) isolated the CFM community from the surface. Prochlorophytes and haptophytes accounted for the largest fraction of total chl a under those conditions. Patterns in pigment ratios found in this study (see Table S4) support the presence of at least 2 different light-acclimated ecotypes: a high light-adapted surface population with a lower DVchlb:DVchla ratio and a low light-adapted deep population (occupying the CFM or deep waters) with a high DVchlb:DVchla ratio (Moore et al. 1995). Such vertical segregation of prochlorophyte populations has been observed in other tropical and subtropical marine ecosystems (Partensky et al. 1993, Moore et al. 1995). Peak prochlorophyte abundance at CFM and in deeper waters occurred during fall in this study even though water column stratification was stronger in summer; this could be attributed to the higher water temperatures in the euphotic zone during fall. Temperatures at CFM and similar depths in fall $(23.06 \pm 1.59)$ were higher than summer $2009(21.79 \pm 0.93)$ and spring $2010(19.33 \pm 0.09)$, when mixed conditions prevailed and prochlorophytes were absent.

Haptophytes, pelagophytes and prasinophytes were also common in CFM and deep populations (Fig. 6). Vertical distribution of these groups likely reflects control by light and nutrients (Marty et al. 2002). Recent studies have shown the importance of pelagophyte subsurface populations (Not et al. 2008), in some cases accounting for as much as $40 \%$ of the total picoeukaryote populations at depth. Besides pelagophytes, prasinophytes belonging to Micromonas and Bathycoccus have also been found to be an important member of picoeukaryote populations at CFM depths and deeper waters of the Gulf of Mexico (Paul et al. 2000, Hernandez-Becerril et al. 2012). Our results are also consistent with Steinberg et al. (2001) and Claustre \& Marty (1995), who found the above phytoplankton groups to be a significant part of the community in the chlorophyll maximum and deep populations in the subtropical and tropical North Atlantic. Conditions in the CFM and deep waters during spring 2010 differed from other periods, a result of upwelling-favorable wind conditions (Huang et al. 2013), relatively high nutrient concentrations, and increased $Z_{\mathrm{m}}$. The prevalence of diatoms and hapto-8 during this period (Fig. 6a) was attributed to these atypical conditions.

\section{Phytoplankton community composition in river plume-influenced offshore waters}

During the course of this study, the freshwater discharge from Mississippi and Atchafalaya rivers significantly impacted the phytoplankton community beyond the inner shelf regions. During summer 2009, relatively high river discharge (Fig. 2) accompanied by winds out of the southwest which persisted for a long period (>30 d) provided an effective combination for transporting large amounts of freshwater and nutrients offshore, as reported in prior studies (Feng et al. 2012, Zhang et al. 2012). Shifting wind patterns out of the south or southwest in the summer months (July and August) can increase transport of the Mississippi and Atchafalaya outflow in the offshore direction beyond the shelf break and to the east (Schiller et al. 2011). Low salinity plume waters from the Mississippi and Atchafalaya river system also extended offshore during spring 2010, with substantial impacts on phytoplankton community composition (Figs. 3b \& 5c) and carbon system properties (Huang et al. 2013). In contrast to the situation in summer months, conditions in March 2010 for our study involved winds out of the northwest.

Although diatoms were the dominant phytoplankton group in the plume-impacted offshore waters in both these summer and spring events, the dominant diatom species differed between the 2 scenarios. Based on microscopic analyses, the plume-impacted offshore stations in summer mainly hosted heavily silicified species of Skeletonema and some Phaeodactylum, while greater than $60 \%$ of the diatoms during spring 2010 belonged to weakly silicified small centric species of Thalassiosira and Chaetoceros, and larger species of Rizosolenia. Therefore, the diatoms in the offshore plume during summer were probably coastal species that had been advected offshore by the southwest winds. This con- 
trasted with spring 2010, when wind-driven export of nutrients probably stimulated growth of native offshore diatom species.

Our results provide evidence that event-scale offshore transport of freshwater and high nutrients from the inner shelf driven by physical and atmospheric forcing beyond the shelf is an important mechanism, leading to significant alterations of offshore phytoplankton communities. Such processes have important biogeochemical implications for export flux of carbon. Moreover, these findings demonstrate that the classical concepts of phytoplankton communities being strongly controlled by mixed layer depth and stratification may not apply under such conditions.

\section{Phytoplankton community composition, carbon export, and regional hypoxia}

The regional and seasonal patterns in phytoplankton community composition detailed in this study provide a basis for speculation as to how differences in trophic structure may be associated with changes in carbon processing in the upper water column. Carbon export from surface waters arguably contributes to the consumption of bottom water oxygen through decomposition of organic matter and is a factor in the recurring hypoxia in this region (Rabalais et al. $2002 b$ ). Food webs in which diatoms are the dominant primary producers are typically associated with higher carbon export efficiencies (Dortch et al. 2001). Diatoms (mainly Skeletonema sp., Coscinodiscus sp., Nitzschia sp., and Thalassiosira sp.) accounted for the majority of the chl $a$ in inner and midshelf waters during spring and summer periods in this study. The average $\mathrm{SiO}_{3}$ :DIN ratio was $>1$, although ratios $<1$ were observed at several stations during spring and summer 2009. Such prevailing conditions have been argued to favor persistent hypoxia (Dortch \& Whitledge 1992, Dortch et al. 2001). However, the areal extent of hypoxia during summer 2009 was the smallest in the previous decade $\left(8000 \mathrm{~km}^{2}\right.$ in comparison to the average of $\sim 13800 \mathrm{~km}^{2}$ from 1985 to 2014; www.gulfhypoxia.net). Bottom water hypoxia (dissolved oxygen $\leq 2 \mathrm{mg} \mathrm{l}^{-1}$ ) was observed only at 5 stations during our 2009 summer cruise. The winddriven transport of the river plume, as described here and previously (Feng et al. 2012, Zhang et al. 2012), may have diverted diatom-dominated plume waters off the shelf, which could at least partially explain the reduced extent of shelf hypoxia in summer 2009. Therefore, processes in addition to nutrient transport and pelagic biology should be fully considered in attempts to understand and predict hypoxia in the NGOM (Bianchi et al. 2010).

\section{CONCLUSIONS}

Our study is unprecedented in spatial and temporal extent in the NGOM and has provided one of the most comprehensive analyses of phytoplankton community composition in relationship to environmental conditions in this region. In addition, this work has contributed to general knowledge about phytoplankton dynamics in large river systems. Our findings support the view that river outflows and their interaction with other environmental variables have a profound influence on phytoplankton communities over a large regional extent in the continental margin waters of the NGOM. Consistent with prior studies, a strong spatial gradient was found in the NGOM with a eukaryotic phytoplankton-dominated system in river-influenced waters in contrast to a mixed assemblage of prokaryotes and eukaryotes in continental slope waters. This study identified water temperature, stratification, and mixed layer depth in addition to salinity as important environmental factors related to phytoplankton community composition. Highly stratified, low nutrient and high temperature (i.e. summer) conditions favored picophytoplankton groups, including cyanobacteria and prochlorophytes, while eukaryotic phytoplankton were more prevalent under mixed or less stratified conditions. The phytoplankton group haptophytes along with the marker pigment 19'-hexanoyloxyfucoxanthin was consistently observed irrespective of mixing conditions. Seasonal shifts in mixing conditions have been considered to be the primary driver of phytoplankton dynamics in the offshore NGOM. However, results from this study showed that under certain wind and current conditions, offshore extensions of the nutrient-enriched Mississippi River water become important and the classical concept of mixing and stratification as dominant factors controlling offshore populations may not apply. Correspondingly, windinfluenced advection of river outflow waters and associated phytoplankton communities may influence patterns of carbon export and the associated areal extent of hypoxia.

The importance of cyanobacteria in the large river dominated margin of the NGOM has been confirmed in this study and the probable contribution of diazotrophic processes in the food web should be considered in future research. In addition, in subsurface waters as observed at the CFM, alternations between 
prochlorophytes and picoeukaryotes may have biogeochemical significance and are potentially important in influencing the sinking particle and dissolved carbon flux to the deep ocean.

Acknowledgements. We thank the captain and crews of R/Vs 'Cape Hatteras' and 'Hugh Sharp' for their assistance. We are grateful for funding support from the National Science Foundation (OCE-0752254) and the National Aeronautics and Space Administration (NNX10AU06G and NNX12AP84G). We also thank V. Lovko for microscopic identification of phytoplankton collected during the cruise and S. Epps for the suspended particulate matter data. S. R. Wright and H. Higgins graciously provided access to the CHEMTAX (v.1.95) software.

\section{LITERATURE CITED}

Bianchi TS, Allison MA, Chapman P, Cowan JH and others (2010) New approaches to the Gulf hypoxia problem. Eos 91:173, doi:10.1029/2010EO190006

Bouman HA, Ulloa O, Scanlan DJ, Zwirglmaier K and others (2006) Oceanographic basis of the global surface distribution of Prochlorococcus ecotypes. Science 312:918-921

> Claustre H, Marty JC (1995) Specific phytoplankton biomasses and their relation to primary production in the tropical north Atlantic. Deep-Sea Res I 42:1475-1493

Dortch Q, Whitledge TE (1992) Does nitrogen or silicon limit phytoplankton production in the Mississippi River plume and nearby regions? Cont Shelf Res 12:1293-1309

Dortch Q, Rabalais NN, Turner RE, Qureshi NA (2001) Impacts of changing $\mathrm{Si} / \mathrm{N}$ ratios and phytoplankton species composition. In: Rabalais NN, Turner RE (eds) Coastal hypoxia: consequences for living resources and ecosystems. Coastal and Estuarine Studies No. 58, American Geophysical Union, Washington, DC, p 37-48

Dunn DD (1996) Trends in nutrient inflows to the Gulf of Mexico from streams draining the conterminous United States, 1972-93. US Geological Survey Water Resources Investigations Report No. 96-4113, Austin, TX

Fahnenstiel G, McCormick MJ, Lang GA, Redalje DG and others (1995) Taxon-specific growth and loss rates for dominant phytoplankton populations from the northern Gulf of Mexico. Mar Ecol Prog Ser 117:229-239

Feng Y, DiMarco SF, Jackson GA (2012) Relative role of wind forcing and riverine nutrient input on the extent of hypoxia in the northern Gulf of Mexico. Geophys Res Lett 39:L09601, doi:10.1029/2012GL051192

Gibb SW, Cummings DG, Irigoien X, Barlow RG, Fauzi R, Mantoura C (2001) Phytoplankton pigment chemotaxonomy of the northeastern Atlantic. Deep-Sea Res II 48: 795-823

> Goes JI, Gomes HdR, Chekalyuk AM, Carpenter EJ and others (2014) Influence of the Amazon River discharge on the biogeography of phytoplankton communities in the western tropical north Atlantic. Prog Oceanogr 120: $29-40$

Heileman S, Rabalais NN (2008) Gulf of Mexico LME. In: Sherman K, Hempel G (eds) A perspective on the changing conditions in LMEs of the world's regional seas. UNEP Regional Seas Report and Studies No. 182. United Nations Environment Programmme, Nairobi, p 673-688
Hernandez-Becerril DU, Aquino-Cruz A, Salas-De-Leon DA, Signoret-Poillon M, Monreal-Gomez MA (2012) Studies on picophytoplankton in the southern Gulf of Mexico: pigment analysis and potential importance of the picoeukaryote prasinophyte Micromonas pusilla. Mar Biol Res 8:331-340

> Huang WJ, Cai WJ, Castelao RM, Wang Y, Lohrenz SE (2013) Effects of a wind-driven cross-shelf large river plume on biological production and $\mathrm{CO}_{2}$ uptake on the Gulf of Mexico during spring. Limnol Oceanogr 58: 1727-1735

Jolliff JK, Kindle JC, Penta B, Helber R and others (2008) On the relationship between satellite-estimated bio-optical and thermal properties in the Gulf of Mexico. J Geophys Res 113:G01024, doi:10.1029/2006JG000373

Justic D, Rabalais NN, Turner RE, Dortch Q (1995) Changes in nutrient structure of river-dominated coastal waters: stoichiometric nutrient balance and its consequences. Estuar Coast Shelf Sci 40:339-356

Ko DS Preller RH, Martin PJ (2003) An experimental realtime intra-Americas sea ocean nowcast/forecast system for coastal prediction. Fifth Conference on Coastal Atmospheric and Oceanic Prediction and Processes, American Meteorological Society Committee on Coastal Environments, 6-8 Aug 2003, Seattle, WA, p 97-100

Lambert CD, Bianchia TS, Santschi PH (1999) Cross-shelf changes in phytoplankton community composition in the Gulf of Mexico (Texas shelf/slope): the use of plant pigments as biomarkers. Cont Shelf Res 19:1-21

> Latasa M (2007) Improving estimations of phytoplankton class abundances using CHEMTAX. Mar Ecol Prog Ser 329:13-21

> Li WKW (1998) Annual average abundance of heterotrophic bacteria and Synechococcus in surface ocean waters. Limnol Oceanogr 43:1746-1753

Li H, Veldhuis MJW, Post AF (1998) Alkaline phosphatase activities among planktonic communities in the northern Red Sea. Mar Ecol Prog Ser 173:107-115

Lindell D, Post AF (1995) Ultraplankton succession is triggered by deep winter mixing in the Gulf of Aqaba (Eilat) Red Sea. Limnol Oceanogr 40:1130-1141

> Lohrenz SE, Fahnenstiel GL, Redalje DG, Lang GA, Dagg MJ, Whitledge TE, Dortch Q (1999) Nutrients, irradiance, and mixing as factors regulating primary production in coastal waters impacted by the Mississippi River plume. Cont Shelf Res 19:1113-1141

> Lohrenz SE, Redalje DG, Cai WJ, Acker J, Dagg M (2008) A retrospective analysis of nutrients and phytoplankton productivity in the Mississippi River plume. Cont Shelf Res 28:1466-1475

- Mackey MD, Mackey DJ, Higgins HW, Wright SW (1996) CHEMTAX - a program for estimating class abundances from chemical markers: application to HPLC measurements of phytoplankton. Mar Ecol Prog Ser 144:265-283

Margalef R (1978) Life-forms of phytoplankton as survival alternatives in an unstable environment. Oceanol Acta 1: 493-509

Marty JC, Chiavérini J, Pizay MD, Avril B (2002) Seasonal and interannual dynamics of nutrients and phytoplankton pigments in the western Mediterranean Sea at the DYFAMED time-series station (1991-1999). Deep-Sea Res II 49:1965-1985

Mitchell BG, Holm-Hansen O (1991) Bio-optical properties of Antarctic Peninsula waters: differentiation from temperate ocean models. Deep-Sea Res A 38:1009-1028 
Moore LR, Goericke R, Chisholm SW (1995) Comparative physiology of Synechococcus and Prochlorococcus: influence of light and temperature on growth, pigments, fluorescence and absorptive properties. Mar Ecol Prog Ser 116:259-276

Moore LR, Anton FP, Rocap G, Chisholm SW (2002) Utilization of different nitrogen sources by the marine cyanobacteria Pochlorococcus and Synechococcus. Limnol Oceanogr 47:989-996

Not F, Latasa M, Scharek R, Viprey M and others (2008) Protistan assemblages across the Indian Ocean, with a specific emphasis on the picoeukaryotes. Deep-Sea Res I 55: 1456-1473

Paerl HW (1996) A comparison of cyanobacterial bloom dynamics in freshwater, estuarine and marine environments. Phycologia 35:25-35

Partensky F, Hoepffner N, Li WKW, Ulloa O, Vaulot D (1993) Photoacclimation of Prochlorococcus sp. (Prochlorophyta) strains isolated from the North Atlantic and the Mediterranean Sea. Plant Physiol 101:285-296

Paul JH, Alfreider A, Wawrik B (2000) Micro- and macrodiversity in $r b c L$ sequences in ambient phytoplankton populations from the southeastern Gulf of Mexico. Mar Ecol Prog Ser 198:9-18

Qian Y, Jochens AE, Kennicutt Ii MC, Biggs DC (2003) Spatial and temporal variability of phytoplankton biomass and community structure over the continental margin of the northeast Gulf of Mexico based on pigment analysis. Cont Shelf Res 23:1-17

Rabalais N, Turner RE, Dortch Q, Justic D, Bierman V Jr, Wiseman W Jr (2002a) Nutrient-enhanced productivity in the northern Gulf of Mexico: past, present and future. Hydrobiologia 475/476:39-63

Rabalais NN, Turner RE, Wiseman WJ Jr (2002b) Gulf of Mexico hypoxia, a.k.a. 'The Dead Zone'. Annu Rev Ecol Syst 33:235-263

Roy S, Llewellyn CA, Egeland ES, Johnsen G (eds) (2011) Phytoplankton pigments: characterization, chemotaxonomy and applications in oceanography. Cambridge University Press, New York, NY

Schaeffer BA, Kurtz JC, Hein MK (2012) Phytoplankton community composition in nearshore coastal waters of Louisiana. Mar Pollut Bull 64:1705-1712

Schiller RV, Kourafalou VH, Hogan P, Walker ND (2011) The dynamics of the Mississippi River plume: impact of topography, wind and offshore forcing on the fate of plume waters. J Geophys Res 116:C06029, doi:10.1029/ 2010JC006883

Editorial responsibility: Antonio Bode, A Coruña, Spain
Schlüter L, Lauridsen TL, Krogh G, Jørgensen T (2006) Identification and quantification of phytoplankton groups in lakes using new pigment ratios - a comparison between pigment analysis by HPLC and microscopy. Freshw Biol 51:1474-1485

Smith WOJ, Demaster DJ (1996) Phytoplankton biomass and productivity in the Amazon River plume: correlation with seasonal river discharge. Cont Shelf Res 16:291-319

> Sommaruga R, Hofer JS, Alonso-Saez L, Gasol JM (2005) Differential sunlight sensitivity of picophytoplankton from surface Mediterranean coastal waters. Appl Environ Microbiol 71:2154-2157

> Steinberg DK, Carlson CA, Bates NR, Johnson RJ, Michaels AF, Knap AH (2001) Overview of the US JGOFS Bermuda Atlantic Time-series Study (BATS): a decadescale look at ocean biology and biogeochemistry. DeepSea Res II 48:1405-1447

> Sylvan JB, Dortch Q, Nelson DM, Brown AF, Morrison W, Ammerman JW (2006) Phosphorus limits phytoplankton growth on the Louisiana shelf during the period of hypoxia formation. Environ Sci Technol 40:7548-7553

- Van Heukelem L, Thomas CS (2001) Computer-assisted high-performance liquid chromatography method development with applications to the isolation and analysis of phytoplankton pigments. J Chromatogr A 910:31-49

Walker ND, Wiseman WJ, Rouse LJ, Babin A (2005) Effects of river discharge, wind stress, and slope eddies on circulation and the satellite-observed structure of the Mississippi River plume. J Coast Res 216:1228-1244

Wawrik B, Paul JH (2004) Phytoplankton community structure and productivity along the axis of the Mississippi River plume in oligotrophic Gulf of Mexico waters. Aquat Microb Ecol 35:185-196

Zapata M, Jeffrey SW, Wright SW, Rodríguez F, Garrido JL, Clementson L (2004) Photosynthetic pigments in 37 species (65 strains) of Haptophyta: implications for oceanography and chemotaxonomy. Mar Ecol Prog Ser 270:83-102

Zhang X, Hetland RD, Marta-Almeida M, DiMarco SF (2012) A numerical investigation of the Mississippi and Atchafalaya freshwater transport, filling and flushing times on the Texas-Louisiana shelf. J Geophys Res 117: C11009, doi:10.1029/2012JC008108

Zhou Mj, Shen Zl, Yu Rc (2008) Responses of a coastal phytoplankton community to increased nutrient input from the Changjiang (Yangtze) River. Cont Shelf Res 28: 1483-1489

Submitted: June 11, 2014; Accepted: November 3, 2014

Proofs received from author(s): January 27, 2015 